\title{
Comparison of Agrotain-treated and standard urea on an irrigated dairy pasture
}

\author{
R.J. MARTIN ${ }^{1}$, T.J. VAN DER WEERDEN ${ }^{2}$, M.U. RIDDLE ${ }^{1}$ and R.C. BUTLER ${ }^{1}$ \\ ${ }^{1}$ Crop \& Food Research, Private Bag 4704, Christchurch \\ ${ }^{2}$ AgResearch, Invermay Agricultural Centre, PB 50034, Mosgiel \\ martind@crop.cri.nz
}

\begin{abstract}
Trials were started in spring, summer and autumn to compare the effect of Agrotain-treated urea and standard urea, at application rates of 25, 50, 75 and $100 \mathrm{~kg} \mathrm{~N} / \mathrm{ha}$, on dairy pasture production on a commercial dairy farm in Canterbury. There were six replicates of these eight treatments, plus two control plots per replicate where no urea was applied. Each trial was mown three times at around the second fully emerged leaf stage, and a subsample taken for dry matter determination. Yields generally increased with increasing rates of urea. There was no difference in pasture yield response between Agrotain-treated urea and standard urea in the wet conditions of the summer trial. In the dry conditions of the spring and autumn trials, Agrotain-treated urea produced $327 \mathrm{~kg} / \mathrm{ha}$ more pasture dry matter than standard urea, although the yield advantage was small (130 kg/ha) at fertiliser application rates of $50 \mathrm{~kg} \mathrm{~N} / \mathrm{ha}$ or less, compared to $524 \mathrm{~kg} / \mathrm{ha}$ at $75 \mathrm{~kg} \mathrm{~N} / \mathrm{ha}$ or more.
\end{abstract}

Keywords: nitrogen, urea, Agrotain, pasture, yield

\section{Introduction}

New Zealand dairy farmers need high yields of pasture for profitable milk production. This requires significant inputs of nitrogen, either as nitrogen fixed by clovers or as $\mathrm{N}$ fertiliser, usually urea, which is the cheapest source of $\mathrm{N}$. However, not all the $\mathrm{N}$ inputs are utilised for grass growth and some are lost by leaching as nitrate or to the atmosphere as ammonia $\left(\mathrm{NH}_{3}\right)$. These losses can be up to $30-40 \%$ of the nitrogen supplied (Edmeades 2004).

Urea applied as a fertiliser or in urine is rapidly hydrolysed to ammonium by urease enzymes (Mobley $\&$ Hausinger 1989). Of the differing $\mathrm{N}$ fertilisers, urea results in the largest $\mathrm{NH}_{3}$ volatilisation losses (Black et al. 1985) due to the temporary lift in soil $\mathrm{pH}$ under the urea granule. This promotes the conversion of the newlyformed ammonium to $\mathrm{NH}_{3}$, which is lost to the atmosphere from the soil surface, especially if the soil surface is wet (Black et al. 1987) Consequently, there has been considerable research into materials that will either inhibit or reduce the activity of the urease enzyme to reduce these losses.

Sustain is currently the only urea fertiliser coated with a urease inhibitor that is commercially available in New Zealand. The active ingredient is Agrotain (N-(n-butyl) thiophosphoric triamide, or nBTPT for short). A $25 \%$ w/w solution of nBTPT in stabiliser solution is coated onto granulated urea at a rate of $1 \mathrm{~L} /$ tonne (Quin et al. 2005). The coated urea can then be applied in the same way as ordinary urea. In the soil, the nBTPT is oxidised to $\mathrm{nBTPTO}$, which rapidly binds to the urease in the soil (Manunza 1999).

Quin et al. (2005) showed a 10\% increase in yields from Agrotain-treated urea compared with standard urea at 30 and $60 \mathrm{~kg} \mathrm{~N} / \mathrm{ha}$ application rates. In a subsequent paper, responses to Agrotain-treated urea applications at two rates of inhibitor and an $\mathrm{N}$ rate equivalent to $600 \mathrm{~kg}$ $\mathrm{N} / \mathrm{h}$ a ranged from 6 to $12 \%$ at Ashburton, and from $-4 \%$ to $6 \%$ at Te Awamutu (Ramakrishnan et al. 2008). Other results from that trial, presented by Blennerhassett et al. (2006), showed that the response varied between seasons, with the biggest responses in summer in Ashburton ( $450 \mathrm{~kg} / \mathrm{ha}$ pasture dry matter), and in winter in Te Awamutu (677 kg/ha).

Ramakrishnan et al. (2008) reported an average N response advantage to Agrotain treated urea over standard urea of $41 \%(23-72 \%)$ over 6 to 16 months in two Waikato and three Canterbury trials, where an average of $25 \mathrm{~kg} \mathrm{~N}$ was applied after each cut. In contrast, at 10 sites from Northland to Southland, Stafford et al. (2008) found the average yield advantage was less than $10 \%(-29 \%$ to $+26 \%$ ) over spring where only 30 or $60 \mathrm{~kg} \mathrm{~N}$ was applied.

The trials described in this paper were carried out to determine whether there was an advantage to using Agrotain-treated urea over standard urea for dairy farmers, and whether that varied between seasons.

\section{Materials and Methods}

All the trials were carried out on a long-term dairy pasture near Kirwee in Canterbury. The soil type was a Lismore Shallow Silt Loam, and the paddock, rotationally grazed and irrigated when required by a centre pivot. The background soil fertility was determined prior to the first trial being established and showed $59 \mathrm{~kg}$ mineralisable $\mathrm{N} / \mathrm{ha}$, pH 5.9, Olsen P $22 \mu \mathrm{g} / \mathrm{ml}$, exchangeable K 5 (MAF Quick Test), exchangeable Ca 7 (MAF Quick Test), exchangeable Mg 9 (MAF Quick Test), Sulphate-S 15 ppm, and CEC $12 \mathrm{me} / 100 \mathrm{~g}$.

Three trials were started in spring 2007, summer 200607, and autumn 2007 (Table 1) with two fertilisers (Agrotain urea, standard urea) at four rates $(25,50,75$ and $100 \mathrm{~kg} \mathrm{~N} / \mathrm{ha}$ ). Six replicates of these eight treatments 
Table 1 Dates of application of Agrotain-treated urea and standard urea in three trials and subsequent harvest dates.

\begin{tabular}{lccccc}
\hline Trial & Application date & First cut & Second cut & Third cut & Trial duration (days) \\
\hline Spring & 19-Sep-06 & 11-Oct-06 & 10-Nov-06 & 12-Dec-06 & 83 \\
Summer & 18-Dec-06 & 18-Jan-07 & 14-Feb-07 & 20-Mar-07 & 92 \\
Autumn & 23-Mar-07 & 24-Apr-07 & 3-Aug-07 & 21-Sep-07 & 182 \\
\hline
\end{tabular}

were used in each trial. Two control (no applied N) plots were also included in each replicate in each trial. Each trial was laid as three columns of 20 plots, as a rowcolumn design, such that there was a complete replicate in each column of 10 plots, chosen so that no treatment appeared more than once in each row of three plots.

The trials were adjacent to each other along a fence line. Each trial was set up by mowing off the original pasture to a height of $5 \mathrm{~cm}$. A rain gauge was placed in the trial area and soil temperature probes installed at a depth of $10 \mathrm{~cm}$ adjacent to the experimental plots. Other meteorological data were also collected from a local NIWA site at Darfield, about $4 \mathrm{~km}$ away.

Once mown, the trial was then marked out and pegged, with each plot $1 \mathrm{~m}$ wide by $5 \mathrm{~m}$ long with a $1 \mathrm{~m}$ buffer between each of the three columns. The treatment fertiliser was broadcast onto the plots by hand from individual paper bags. Trial fertiliser application dates are given in Table 1. The farmer agreed not to irrigate the paddock for at least 5 days after fertiliser application.

Each trial was harvested on three occasions, each time at around the second fully emerged leaf stage (Table 1). A single mown strip was then taken down the middle of every plot to a height of $5 \mathrm{~cm}$ and this was weighed and subsampled for dry matter determination.

Initial analyses indicated that the patterns found for the total yields were present in a similar way at each cut, and so analyses of variance were carried out on the combined yields from each plot using GenStat $\left(9^{\text {th }}\right.$ Edition, VSN International, Hemel Hempstead UK, 2006). A level of $\mathrm{P}=0.05$ was used to determine significance. For the autumn trial, data for one plot were omitted as an outlier, as it had double the yields of any other plot.

\section{Results}

Rainfall and soil temperature data around the fertiliser applications for the three trials are given in Table 2. During the 5 days after the treatments were applied, it was hoped that no significant rainfall would occur, to attempt to quantify the maximum benefit of using Agrotain-treated urea.

The "no rain" requirement was met for the spring and autumn trials. For the summer trial, no rain fell in the first 24-48 hours, but then there was $45 \mathrm{~mm}$ of rain the next day. That trial also had significant rainfall both prior to fertiliser application and in the 8-15 days after fertiliser application, so the soil in that trial would have been moist over most of the detailed measuring period. The autumn trial also had rain before fertiliser application, and so the soil surface was likely to be moist.

Mean 9 am soil temperatures at a $10 \mathrm{~cm}$ depth over the 7 days subsequent to fertiliser application were $2^{\circ} \mathrm{C}$ higher in the autumn trials than in the summer trial, and $5^{\circ} \mathrm{C}$ higher than the spring trial.

There were significant differences in pasture yield between some treatments for all three of the trials $(\mathrm{P}<0.05)$ (Table 3). In all three trials, application of Agrotain urea and standard urea increased yield compared with the Nil controls. The only exception was in the autumn 2007 trial when yield in the Nil treatments was not significantly different from both urea and Agrotain-treated urea applied at 25 and $50 \mathrm{~kg} / \mathrm{ha}$. On average, yield increased with increasing rates of applied $\mathrm{N}(\mathrm{P}<0.05)$.

There were no significant pasture yield differences between the fertiliser types for the summer trial. However, in the spring trial, there was a significant difference between the fertilisers $(\mathrm{P}=0.001)$, with yield increasing more rapidly with increasing rates of $\mathrm{N}$ for Agrotain urea than for standard urea. At the lowest level of applied N, this difference was quite small $(66 \mathrm{~kg})$, but the difference increased with rate: 258 at $50 \mathrm{~kg} / \mathrm{ha} \mathrm{N}$, to 358 at $75 \mathrm{~kg} / \mathrm{ha} \mathrm{N}$, to $606 \mathrm{~kg}$ at the highest rate of 100 $\mathrm{kg} / \mathrm{ha}$. Only at the highest rate of $100 \mathrm{~kg} \mathrm{~N} / \mathrm{ha}$ was there a significant difference between the fertiliser types (Table 3 ). In the autumn trial, there was a significant difference in yield observed at the two higher rates $(75$ and $100 \mathrm{~kg} /$ ha) for Agrotain urea compared to standard urea.

\section{Discussion}

There was no significant difference in pasture production between Agrotain-treated urea and standard urea when applied in summer 2007 at all levels of $\mathrm{N}$ application. In this trial, a combination of $34 \mathrm{~mm}$ rainfall before fertiliser application, $45 \mathrm{~mm}$ rainfall in the 7 days after application, and a further $31 \mathrm{~mm}$ in the 8 days after that, would mean that most of the urea would have been carried into the soil. There could have been some volatilisation in the 24-48 hours after fertiliser application, as Black et al. (1987) found that up to $31 \%$ of applied $\mathrm{N}$ as urea was volatilised from soil at field capacity in 24 hours, with lesser amounts for drier soil. However, the $42 \mathrm{~mm}$ of rain recorded in the 
Table 2 Total rainfall data for (a) 10 days previous to fertiliser application; (b) 7 days subsequent to fertiliser application; (c) 8-15 days after fertiliser application; together with (d) mean 9 am $10 \mathrm{~cm}$ soil temperatures for the 7 days subsequent to fertiliser application. Rainfall data are from the Darfield Meteorological Station, and $10 \mathrm{~cm}$ soil temperatures were measured in the trials.

\begin{tabular}{lcccc}
\hline Trial & $\begin{array}{c}\text { (a) Rainfall } \\
\text { preceding 10 } \\
\text { days }(\mathrm{mm})\end{array}$ & $\begin{array}{c}\text { (b) Rainfall } \\
\text { subsequent } 7 \\
\text { days }(\mathrm{mm})\end{array}$ & $\begin{array}{c}\text { (c) Rainfall } \\
\text { subsequent } 8-15 \\
\text { days }(\mathrm{mm})\end{array}$ & $\begin{array}{c}\text { (d) Mean 10 cm soil } \\
\text { temperatures } 7 \text { days } \\
\text { subsequent }\left({ }^{\circ} \mathrm{C}\right)\end{array}$ \\
\hline Spring 2006 & 5 & 3 & 2 & 9.3 \\
Summer 06/07 & 34 & 45 & 31 & 12.2 \\
Autumn 2007 & 34 & 5 & 11 & 14.6 \\
\hline
\end{tabular}

Table 3 Mean total yields $(\mathrm{kg} \mathrm{DM} / \mathrm{ha})$ after application of four rates $(\mathrm{kg} / \mathrm{ha})$ of urea $(\mathrm{U})$ and Agrotain-treated urea (A) in spring 2006, summer 2006/2007 and autumn 2007 in three separate trials.

\begin{tabular}{lccc}
\hline Treatment and rate & Spring 2006 & Summer 06/07 & Autumn 2007 \\
\hline Nil 0 & 4763.6 & 4712.1 & 4627.3 \\
A 25 & 5433.5 & 5342.1 & 4818.9 \\
A 50 & 6170.7 & 5864.3 & 5027.7 \\
A 75 & 6344.5 & 5965.9 & 5725.8 \\
A 100 & 6885.5 & 6456.8 & 5970.3 \\
U 25 & 5367.2 & 5573.1 & 4704.8 \\
U 50 & 5912.7 & 5580.8 & 4946.7 \\
U 75 & 5986.5 & 5934.1 & 5195.6 \\
U 100 & 6279.1 & 6408.1 & 5369.4 \\
Lsd 5\% (d.f.=46 ${ }^{1}$ ) & & & \\
Nil vs. any Treatment & 319.5 & 433.0 & 444.9 \\
To compare 2 treatments & 368.9 & 500.0 & 513.7 \\
\hline
\end{tabular}

145 d.f. for Autumn trial

24 hours to 8 am on the third day after application would have washed the remaining urea and urea breakdown products into the soil, since Black et al. (1987) suggested that $16 \mathrm{~mm}$ was sufficient to do this. There would appear to have been enough urea and urea breakdown products washed in from the standard urea to result in no overall difference in pasture growth between Agrotain-treated urea and standard urea.

In the spring and autumn trials, Agrotain-treated urea produced significantly more pasture dry matter than standard urea. This difference in pasture production was strongly influenced by the difference in pasture response at the higher $\mathrm{N}$ rates. The pasture yield responses from these two trials were very similar, with the yield advantage to Agrotain-treated urea increasing from $2 \%$ at $25 \mathrm{~kg} \mathrm{~N} /$ ha to $10 \%$ at $100 \mathrm{~kg} \mathrm{~N} / \mathrm{ha}$. Black et al. (1985) found a proportional increase in $\mathrm{N}$ volatilisation losses with increasing urea application rates, and attributed it to an increase in soil surface $\mathrm{pH}$ increasing the amount of urea hydrolysed to ammonium carbonate.

The spring and autumn trials were both characterised by very little rainfall in the 15 days after fertiliser application. However, Black et al. (1987) showed that, although volatilisation from dry soils proceeds at a slower rate than from wet soils, much of the hydrolysed urea is lost by volatilisation by 30 days after fertiliser application.

Dairy farmers tend to apply small amounts of urea (up to $50 \mathrm{~kg} \mathrm{~N} / \mathrm{ha}$ ) at intervals through the season and, at these rates, even under the relatively dry conditions encountered in the spring and autumn trials, the pasture production differences between the two fertiliser types was not significant.

So how does this match up with previous research? Our yield advantage of Agrotain-treated urea over standard urea ranged from $0 \%$ to $9 \%$, with an average of $5 \%$, similar to data presented by Stafford et al. (2008). If the Canterbury data presented by Ramakrishnan et al. (2008) is analysed in the same way, then their yield advantage to Agrotain-treated urea in Canterbury ranged from 6 to $13 \%$, with an average of $10 \%$. Similarly, the Ashburton data of Blennerhassett et al. (2006) showed a 7\% yield advantage to Agrotain-treated urea. Conversely, if our data are analysed the same way as Ramakrishnan et al. (2008), i.e. comparing the yield responses of both Agrotain-treated urea and standard urea to the control, then the response advantage of Agrotain-treated urea ranged from $-3 \%$ to $32 \%$ (average $21 \%$ ), compared to a range of $23 \%$ to $72 \%$ (average $41 \%$ ) of Ramakrishnan et al. (2008) and an average of 34\% for the Ashburton data of Blennerhassett et al. (2006). So our results are similar to previous studies, and indicate small, but variable, pasture yield increases of Agrotain-treated urea over standard urea in Canterbury. 


\section{Conclusions}

- In this limited set of trials on a single site, Agrotaintreated urea increased dairy pasture yields more than standard urea in situations where irrigation and rainfall was not sufficient to wash the broadcast fertiliser into the soil.

- There was no significant difference in pasture production between Agrotain-treated and standard urea at fertiliser application rates of $50 \mathrm{~kg} \mathrm{~N} / \mathrm{ha}$ or less, but the difference increased with higher application rates.

- Where there was sufficient water to wash the fertiliser in, then there appeared to be no yield advantage in using Agrotain-treated urea over standard urea.

\section{ACKNOWLEDGEMENTS}

Funding for this project was provided by Ravensdown Fertiliser Co-operative Limited. We thank Selwyn and Jenny McLachlan and Paul and Ingrid Rabbidge for allowing us to run the trials on their farm, and Sarah Sinton, Richard Gillespie and Shane Maley for assistance.

\section{REFERENCES}

Black, A.S.; Sherlock, R.R.; Smith, N.P.; Cameron, K.C.; Goh, K.M. 1985. Effects of form of nitrogen, season and urea application rate on ammonia volatilisation from pastures. New Zealand Journal of Agricultural Research 28: 469-474.

Black, A.S.; Sherlock, R.R.; Smith, N.P. 1987. Effects of timing of simulated rainfall on ammonia volatilisation from urea, applied to soil of varying moisture content. Journal of Soil Science 38: 679-687.

Blennerhassett, J.D.; Quin, B.F.; Zaman, M.; Ramakrishnan, C. 2006. The potential for increasing nitrogen responses using Agrotain treated urea.
Proceedings of the New Zealand Grassland Association 68: 297-301.

Edmeades, D. 2004. Nitrification and Urease Inhibitors. Environment Bay of Plenty Environmental Publication 2004/11.23 p. http://www.ebop.govt.nz/ water/media/pdf/nitrification.pdf

Manunza, B.; Deiana, S.; Pintore, M.; Gessa, C. 1999. The binding mechanism of urea, hydroxamic acid and $\mathrm{N}$-(N-butyl)-phosphoric triamide to the urease active site. A comparative molecular dynamics study. Soil Biology and Biochemistry 31: 789-796.

Mobley, H.L.T.; Hausinger, R.P. 1989. Microbial ureases: significance, regulation, and molecular characterization. Microbiological Reviews 53: 85108.

Quin, B.F.; Blennerhassett, J.D.; Zaman, M. 2005. The use of urease inhibitor-based products to reduce nitrogen losses from pasture. pp 288-304. In: Developments in fertiliser application technologies and nutrient management. Eds. Currie, L.D.; Hanly, J.A. Occasional Report No. 18. Fertilizer and Lime Research Centre, Massey University, Palmerston North, New Zealand.

Ramakrishnan, C.; Zaman, M.; Blennerhassett, J.D.; Livermore, N. 2008. Improving the efficiency of N fertilisers. pp 278-285. In: Carbon and nutrient management in agriculture. Eds. Currie, L.D.; Yates, L.J. Occasional Report No. 21. Fertilizer and Lime Research Centre, Massey University, Palmerston North, New Zealand.

Stafford, A; Catto, W.; Morton, J. 2008. Balance AgriNutrients approach to sustainable fertiliser use. pp 197-205. In: Carbon and nutrient management in agriculture. Eds. Currie, L.D.; Yates, L.J. Occasional Report No. 21. Fertilizer and Lime Research Centre, Massey University, Palmerston North, New Zealand. 